\title{
ATLAS OF THE ORAL AND MAXILLOFACIAL SURGERY CLINICS OF NORTH AMERICA
}

\section{FORTHCOMING ISSUES}

\section{September 2016}

Upper Facial Rejuvenation

Faisal A. Quereshy, Editor

\section{March 2017}

Management of Mandibular Condylar Fractures Martin B. Steed, Editor

\section{PREVIOUS ISSUES}

\section{September 2015}

Adjuncts for Care of the Surgical Patient Sidney L. Bourgeois Jr, Editor

\section{March 2015}

Diagnosis and Management of Neck Masses David E. Webb, Editor

\section{September 2014}

Syndromes of the Head and Neck Dean M. DeLuke, Editor

\section{RELATED INTEREST}

Oral and Maxillofacial Surgery Clinics of North America, November 2015, Volume 27, Issue 4 Management of Medication-related Osteonecrosis of the Jaw

Salvatore L. Ruggiero, Editor

Available at: www.oralmaxsurgery.theclinics.com

THE CLINICS ARE NOW AVAILABLE ONLINE! 